\title{
EFEKTIVITAS PEMBELAJARAN KOOPERATIF DITINJAU DARI PENINGKATAN KEMAMPUAN PENALARAN LOGIS MATEMATIS SISWA
}

Oleh:

\author{
Karman Lanani \\ Pendidikan Matematika, FKIP Universitas Khairun Ternate \\ karmanlanani@gmail.com
}

\begin{abstract}
ABSTRAK
Masalah penelitian ini adalah rendahnya kemampuan penalaran logis matematis siswa. Penelitian ini bertujuan untuk mendeskripsikan efektifitas pembelajaran kooperatif ditinjau dari peningkatan kemampuan penalaran logis matematis siswa SMA. Penelitian ini berbentuk quasi eksperimen dengan desain kelompok kontrol pretes-postes. Sampel penelitian ini berjumlah 38 siswa yang diambil secara proposive sampling dari dua kelas siswa pada suatu sekolah swasta di Kabupaten Halmahera Selatan. Penelitian ini mempunyai dua variabel, yaitu: pembelajaran kooperatif sebagai variabel bebas, dan kemampuan penalaran logis matematis siswa sebagai variabel tak bebas. Intrumen yang digunakan untuk pengumpulan data adalah tes kemampuan penalaran logis matematis. Data primer yang diperoleh dari penerapan instrumen tes tersebut, dianalisis menggunakan statistik uji OneSample Test pada taraf signifikansi $\alpha=5 \%$. Hasil penelitian menunjukkan bahwa kemampuan penalaran logis matematis siswa SMA melalui pembelajaran kooperatif mencapai $74,97 \%$ dalam kualifikasi baik dan peningkatannya mencapai 0,72 tergolong tinggi.
\end{abstract}

Kata Kunci : Penalaran Logis Matematis, Kemampuan Penalaran Logis Matematis Siswa, dan Pembelajaran Kooperatif

\begin{abstract}
The research problem is the lack of logical mathematical reasoning abilities of students. This study aimed to describe the effectiveness learning cooperative in terms of improvement of mathematical logical reasoning abilities of high school students. This form of quasiexperimental research design with pretest-posttest control group. Sample size was 38 students were taken proposive sampling of two classes of students at a private school in South Halmahera. This study has two variables, namely: cooperative learning as independent variables, and logical mathematical reasoning abilities of students as dependent variables. Instruments used for data collection is a logical mathematical reasoning ability tests. Primary data were obtained from the application of the test instrument, were analyzed using a statistical test of the One-Sample Test at significance level $\alpha=5 \%$. The results showed that the logical mathematical reasoning abilities of high school students through cooperative learning reaches $74.97 \%$ in both qualifying and the increases were relatively high 0.72 .
\end{abstract}

Keywords: Mathematical Logical Reasoning, Mathematical Logical Reasoning Ability Students, and Cooperative Learning 


\section{PENDAHULUAN}

Matematika merupakan ilmu pengetahuan eksak dan terorganisir secara sistematik. Sebagai ilmu pengetahuan, matematika memiliki aspek logis dan kritis yang tersusun secara konsisten. Pengetahuan matematika dibentuk melalui berpikir mengenai pengalaman suatu obyek atau kejadian tertentu. Obyek matematika dimaksud memotivasi setiap jenjang pendidikan untuk mempelajari matematika. Menurut Gallagler dan Reid (2002) bahwa pengetahuan matematika diperoleh dari abstraksi reflektif berdasarkan koordinasi, relasi, atau penggunaan obyek.

Terbentuknya kemampuan penalaran logis matematis siswa diperlukan kemampuan menerapkan ilmu pengetahuan dan pengalaman guru dalam pembelajaran matematika. Perry dan Potter (2005) bahwa berpikir kritis adalah suatu proses dimana seseorang atau individu dituntut untuk menginterpretasikan dan mengevaluasi informasi untuk membuat sebuah penilaian atau keputusan berdasarkan kemampuan, menerapkan ilmu pengetahuan dan pengalaman. Selanjutnya, Shufer dan Pierce (Sumarmo, 2004) mendefinisikan penalaran logis sebagai proses pencapaian kesimpulan logis berdasarkan fakta-fakta dan sumber yang relevan.

Pembelajaran yang pada umumnya dilaksanakan oleh guru lebih banyak menekankan pada aspek pengetahuan dan pemahaman, sedangkan aspek aplikasi, analisis, sintesis, dan bahkan evaluasi hanya sebagian kecil dari pembelajaran yang dilakukan. Guru selama ini lebih banyak memberi ceramah dan latihan mengerjakan soal-soal dengan cepat tanpa memahami konsep matematika secara mendalam. Hal ini menyebabkan siswa kurang terlatih untuk mengembangkan keterampilan penalaran dalam memecahkan permasalahan dan mengaplikasikan konsep-konsep yang telah dipelajari dalam kehidupan nyata sehingga kemampuan penalaran logis siswa kurang dapat berkembang dengan baik.

Pola pembelajaran yang dikembangkan di Indonesia dewasa ini, menuntut keaktifan siswa dalam proses kegiatan belajar mengajar, dan kreatifitas siswa untuk mengolah materi yang diberikan guru. Hal ini dimaksudkan agar terjadinya pengkontruksian penalaran secara bermakna, berpikir secara kritis dalam menganalisis maupun memecahkan suatu permasalahan matematika yang dipelajarinya. Menurut Spliter (1991) bahwa siswa yang berpikir kritis adalah siswa yang mampu mengidentifikasi, mengevaluasi, dan mengkontruksi argumen serta mampu memecahkan masalah dengan tepat (dalam Redhana 2003: 12-13). Siswa yang berpikir kritis akan mampu menolong dirinya atau orang lain dalam memecahkan permasalahan yang dihadapi.

Suatu pekerjaan mendasar bagi guru dewasa ini adalah mengembangkan proses pembelajaran yang mampu menfasilitasi terbentuknya situasi belajar yang menyenangkan sehingga siswa dapat mengembangkan penalaran logis. Menciptakan situasi pembelajaran yang menyenangkan, dengan semangat kerjasama yang 
bijaksana dan kreatif dapat dilakukan melalui pembelajaran kooperatif. Keramati (2001) bahwa pembelajaran kooperatif memberikan situasi belajar yang menyenangkan untuk semua siswa, semua siswa memiliki kesempatan yang sama, persaingan diubah sebagai persahabatan, semangat kerjasama dan partisipasi diperkuat, dan semua siswa berhak untuk menjadi bijaksana dan kreatif.

Suatu permasalahan penting yang perlu dipecahkan dalam peningkatan kualitas pembelajaran saat ini adalah rendahnya kemampuan penalaran logis matematis siswa. Hal ini ditunjukkan melalui kelemahan siswa untuk mengidentifikasi kebenaran pernyataan majemuk implikasi tentang, "jika diskriminan $x^{2}-5 x+6=0$ sama dengan 0 , maka penyelesaian $x^{2}-5 x+6=0$ tidak mempunyai dua akar real berlainan". Akibat kurangnya kemampuan siswa dalam mengidentifikasi kebenaran pernyataan-pernyataan tunggal, maka siswa juga belum dapat memberikan kesimpulan kebenaran pernyataan majemuk tersebut sebagai pernyataan majemuk implikasi yang bernilai benar atau bernilai salah.

Berdasarkan uraian latar belakang di atas dan memperhatikan kelemahan yang dialami siswa peneliti tertarik melakukan penelitian tentang efektivitas pembelajaran kooperatif dalam meningkatkan kemampuan penalaran logis matematis siswa SMA. Permasalahan yang ingin dijawab dari penelitian ini, yaitu: (1) Apakah pembelajaran kooperatif dapat meningkatkan kemampuan penalaran logis matematis pada siswa SMA? (2) Apakah penerapan pembelajaran kooperatif efektif dalam meningkatkan kemampuan penalaran logis matematis pada siswa SMA? Tujuan penelitian ini adalah untuk mengetahui keefektifan pembelajaran kooperatif dalam meningkatkan kemampuan penalaran logis matematis siswa SMA. Hasil penelitian ini diharapkan menjadi bahan pengetahuan bagi guru tentang penalaran logis matematis dan penerapan pembelajaran kooperatif dalam meningkatkan kemampuan penalaran logis matematis siswa pada pembelajaran matematika.

\section{KAJIAN PUSTAKA}

\section{Penalaran Logis Matematis}

Penalaran merupakan terjemahan dari kata reasoning. Shurter dan Pierce dalam Sastrosudirjo (1988) mendefinisikan penalaran sebagai proses pencapaian kesimpulan logis berdasarkan fakta dan sumber yang relevan. Sastrosudirjo (1988) mengungkapkan bahwa penalaran merupakan salah satu kompetensi dasar matematis disamping pemahaman, komunikasi dan pemecahan masalah. Penalaran merupakan proses berfikir yang dilakukan dengan satu cara untuk menarik kesimpulan. Kesimpulan yang bersifat umum dapat ditarik dari kasus-kasus yang bersifat khusus. Sebaliknya, dari kasus yang bersifat khusus dapat ditarik kesimpulan yang bersifat umum. 
Menurut Copi (1982) bahwa penalaran adalah bentuk khusus dari berpikir dalam upaya pengambilan kesimpulan dan pengambilan konklusi yang digambarkan premis. Selain itu, Glass \& Holyoak (1986) menjelaskan bahwa penalaran adalah simpulan berbagai pengetahuan dan keyakinan mutahir. Kaitannya dengan definisi penalaran tersebut, Galotti (dalam Matlin, 1994) menyatakan bahwa penalaran logis berarti mentransformasikan informasi yang diberikan untuk memperoleh suatu konklusi.

Matlin (1994: 290) mengemukakan 2 (dua) tipe penalaran logis matematis, yaitu: (1) penalaran kondisional, dan (2) penalaran silogisme. Penalaran kondisonal berhubungan dengan pernyataan atau proposisi: "jika...maka..." bagian jika disebut anteseden, sedangkan bagian maka disebut konsekuen. Pernyataan kondisional tidak menegaskan bahwa antesedennya benar atau konsekuensinya benar adalah bernilai benar (B). Namun pernyataan kondisional hanya menyatakan bahwa antesedennya mengakibatkan konsekuennya. Sedangkan, penalaran silogisme adalah suatu argumen yang secara formal dinyatakan dengan dua premis dan satu konklusi (Scwartz, 1994: 107).

\section{Logika Matematika SMA}

Logika berasal dari bahasa Yunani, "logos" berarti kata, ucapan, pikiran secara utuh atau bisa pula berarti ilmu pengetahuan (Kusumah, 1986). Logika matematika adalah pola berpikir berdasarkan penalaran dan dapat diuji kebenarannya. Mencermati pengertian logika tersebut, maka logika matematika merupakan bagian penting dari matematika yang memberikan dasar berpikir yang logis dan sistimatis. Sehingga logika matematika perlu diajarkan pada semua jenis sekolah, dalam hal ini sekolah menengah atas (SMA) atau sederajat.

Materi logika matematika yang dipelajari di SMA meliputi: kalimat terbuka, nilai kebenaran suatu pernyataan, kalimat majemuk dan ingkarannya, konjungsi, disjungsi, implikasi dan biimpliasi. Pernyataan majemuk konjungsi, disjungsi, implikasi dan biimplikasi dan nagasinya merupakan konsep dasar materi logika matematika yang perlu dipahami secara lebih mendalam oleh siswa sebelum melakukan pengembangan ke materi logika matematika yang meliputi: (1) Ekuivalensi, tautology, kontradiksi, dan kontingensi, (2) Konvers, invers, dan kontraposisi, (3) Pernyataan berkuantor, dan (4) Penarikan kesimpulan.

Oleh karena itu, proses pembelajaran logika matematika tentang konjungsi, disjungsi, implikasi dan biimplikasi khususnya di sekolah lanjutan atas (SMA) perlu dilakukan secara mendalam pada bagaimana memahami dan menyusun suatu pernyataan majemuk, nilai kebenarannya dan nagasinya, baik dalam bentuk pernyataan logika matematika maupun non matematika. Hal ini dimaksudkan agar siswa memiliki kemampuan penalaran logis yang mendalam sehubungan dengan konten matematika. 
Pengembangan kemampuan siswa SMA dalam mempelajari materi logika matematika diperlukan kemampuan guru dalam menghubungkan didaktis antara siswa dengan materi pelajaran, hubungan pedagogis antara guru dan siswa, serta hubungan antisipasi guru dengan materi pelajaran. Dengan menggunakan pembelajaran kooperatif, guru dengan kemampuan profesional yang dimilikinya, diharapkan dapat mengkomunikasikan materi pelajaran sehingga siswa dapat membuat sejumlah contoh-contoh pernyataan logika matematika, pernyataan majemuk dan nagasinya serta mampu membuktikan nilai kebenaran dari suatu pernyataan tunggal atau majemuk. Semakin banyak variasi pernyataan logika matematika yang dikembangkan siswa dalam komunikasinya dengan materi pelajaran matematika menunjukkan semakin baik kemampuan penalaran logis dan berpikir kritis yang dimiliki siswa.

Penerapan pembelajaran kooperatif dimana terjadi diskusi kelompok antara siswa, akan menimbulkan sejumlah pertanyan mendasar berkaitan dengan logika matematika, antara lain: (1) Mengapa perlu mempelajari logika matematika?, (2) bagaimana perbedaan pernyataan, kalimat terbuka, dan kalimat perintah?, (3) Apakah semua materi matematika dan non matematika dapat disusun menjadi pernyataan logika, baik dalam bentuk pernyataan tunggal maupun pernyataan majemuk?, (4) Bagaimana implementasi materi logika dalam kondisi nyata? Dimana batasan keluasan materi logika matematika dan non matematika?

Upaya meningkatkan kemampuan penalaran logis matematis siswa SMA terhadap mata pelajaran matematika, khususnya materi Logika Matematika diperlukan kemampuan profesionalisme guru dalam proses pembelajaran kooperatif. Kemampuan profesionalisme dimaksud adalah bagaimana guru dapat mengimplementasikan segitiga didaktik yang dikemukakan Kansenan yang dimodifikasi oleh Suryadi (2010) menggambarkan hubungan didaktis (HD) antara siswa dan materi, dan hubungan pedagogis (HP) antara guru dan siswa, serta hubungan antisipatif guru-materi yang selanjutnya bisa disebut sebagai Antisipasi Didaktis dan Pedagogis (ADP) sebagaimana diilustrasikan pada gambar segitiga didaktis yang dimodifikasi dibawah ini.

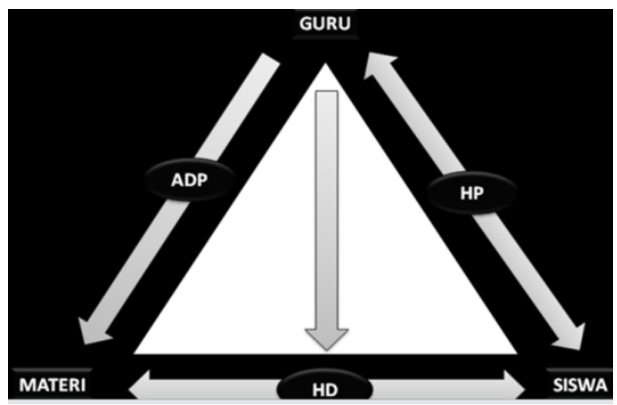

Gambar 1 : Segitiga Didaktis yang Dimodifikasi 
Pemahaman terhadap konteks segitiga didaktis tersebut mengantarkan kemampuan guru untuk menciptakan situasi didaktis (didactical situation), menguasai materi ajar, memiliki keterampilan menggunakan pendekatan pembelajaran terkait dengan materi yang diajarkan serta mampu menciptakan situasi didaktis yang dapat mendorong proses belajar siswa secara optimal. Apabila pembelajaran materi logika matematika diterapkan melalui pembelajaran kooperatif secara optimal dengan memperhatikan hubungan didaktis tersebut secara baik, maka apa yang diharapkan sebagai tujuan pembelajaran dapat tercapai.

\section{Pembelajaran Kooperatif}

Cooperatif learning (pembelajaran kooperatif) adalah salah satu bentuk pembelajaran yang berdasarkan faham konstruktivis. Pembelajaran kooperatif merupakan strategi belajar dengan sejumlah siswa sebagai anggota kelompok kecil yang tingkat kemampuannya heterogen. Menurut Slavin dalam Isjoni (2010: 12) bahwa, pembelajaran kooperatif adalah suatu model pembelajaran dimana siswa belajar dan bekerja dalam kelompok-kelompok kecil secara kolaboratif yang anggotanya 4-6 orang dengan struktur kelompok heterogen.

Menurut Slavin (dalam Mohammadi, 2008) bahwa terdapat empat prinsip pembelajaran kooperatif yang memainkan peran penting dalam teknik mengajar, yaitu: Prinsip pertama, menekankan pada sifat sosial pembelajaran, yang menurut anak-anak melalui interaksi dengan orang dewasa dan teman sebaya yang lebih kompeten. Prinsip ke-dua, mengemulasi Zona Proksimal Perkembangan (ZPD). Vygotsky (1978) menjelaskan bahwa perkembangan proksimal diperkirakan berbeda antara "Perkembangan proksimal saat ini" kemampuan anak yang mandiri untuk memecahkan masalah, dan "Pengembangan potensi Proksimal" kemampuan anak untuk memecahkan masalah dengan bimbingan orang dewasa atau kerjasama dengan rekan yang lebih terampil. Prinsip ke-tiga adalah pelatihan kognitif dan berkaitan dengan proses dimana peserta didik memperoleh kompetensi secara bertahap melalui interaksi dengan orang terampil (dewasa atau teman sebaya yang lebih tua dan lebih terampil). Vygotsky menekankan pada pembelajaran yang mendukung melalui media dalam pemikiran konstruktivis modern.

Pembelajaran kooperatif mendorong perilaku siswa menjadi lebih positif, mengembangkan minat, dan membantu meningkatkan kepercayaan dan harga diri siswa (Sharan, 1980; Mirzakhani et al, 2008; Dehghan Shadkami, 2009; Zourabadi,2003). Temuan penelitian menunjukkan bahwa pembelajaran kooperatif meningkatkan kepercayaan dan saling menghormati, penurunan kecemasan, mempromosikan meta-kognitif pengetahuan dan mendorong martabat diri dan antusias terhadap pembelajaran (Johnson \& Johnson, 1989; Millis, 2010; Slavin \& Karaweit, 1981; Ayoubi, 1998). Kelanjutan hasil pembelajaran kooperatif lebih banyak merenungkan perhatian dan konsentrasi, meningkatkan memori, pemahaman 
dan wawasan, memperluas resolusi analitis dan penilaian pada bagian pengetahuan ilmiah (Johnson \& Johnson, 1999).

Berdasarkan uraian diatas, dapat dikatakan bahwa pembelajaran kooperatif dimana siswa belajar dalam kelompok kecil berjumlah (4-6 orang) dengan kemampuan yang heterogen secara kolaboratif untuk membahas suatu masalah tertentu dengan bimbingan orang dewasa atau teman sebaya yang berkompeten. Pembelajaran kooperatif mendorong terjalinnya kerjasama yang harmonis dan saling mendukung sehingga terbentuknya perilaku positif siswa, mengembangkan minat, membantu meningkatkan kepercayaan diri, meningkatkan pemahaman dan wawasan, serta menurunkan kecemasan.

\section{Karakteristik Pembelajaran Kooperatif}

Pembelajaran kooperatif merupakan suatu model pembelajaran yang banyak digunakan untuk mewujudkan kegiatan belajar mengajar. Pelaksanaan pembelajaran kooperatif berpusat pada siswa (student oriented). Pembelajaran ini mengatasi permasalahan yang ditemukan guru dalam mengaktifkan siswa yang tidak dapat bekerja sama dengan orang lain, siswa yang agresif dan tidak peduli pada orang lain, dan telah terbukti dapat dipergunakan dalam berbagai mata pelajaran dan dalam berbagai usia peserta didik.

Menurut Roger dan David (dalam Suprijono, 2010: 58) bahwa tidak semua belajar berkelompok bisa dianggap pembelajaran kooperatif. Prosedur pelaksanaan model pembelajaran kooperatif yang benar akan memungkinkan guru mengelola kelas lebih efektif. Beberapa ciri dari pembelajaran kooperatif adalah setiap anggota memiliki peran, terjadi hubungan interaksi langsung diantara siswa, setiap anggota kelompok bertanggung jawab atas belajarnya dan juga teman-teman sekelompoknya, guru membantu mengembangkan keterampilan-keterampilan interpersonal kelompok, dan guru hanya berinteraksi dengan kelompok saat diperlukan.

\section{Penerapan Pembelajaran Kooperatif}

Menciptakan lingkungan yang optimal, baik secara fisik maupun mental, dengan cara menciptakan suasana kelas yang nyaman, suasana hati yang gembira tanpa tekanan, maka dapat memudahkan siswa dalam memahami materi pelajaran. Terciptanya suasana kelas yang mendorong terbentuknya kemampuan berpikir dan bernalar pada siswa, menurut Isjoni (2010:61) diperlukan kemauan dan kemampuan serta kreativitas guru dalam pengelolaan kelas. Dalam pembelajaran kooperatif, guru harus lebih aktif terutama saat menyusun rencana pembelajaran secara matang, pengaturan kelas saat pelaksanaan, dan membuat tugas yang menantang untuk dikerjakan siswa secara bersama dengan kelompoknya. 
Menurut Hasan (dalam Isjoni, 2010) bahwa penerapan pembelajaran kooperatif, hendaknya guru mampu memposisikan diri sebagai fasilitator, mediator, directormotivator dan evaluator secara profesional. Sebagai fasilitator guru harus memiliki kemampuan: (1) menciptakan suasana kelas yang nyaman dan menyenangkan, (2) membantu dan mendorong siswa untuk menjelaskan keinginan secara individu maupun kelompok, (3) membantu menyediakan sumber atau peralatan guna kelancaran belajar siswa, (4) membina setiap siswa agar bermanfaat bagi yang lain, (5) menjelaskan tujuan kegiatan pada kelompok dan mengatur penyebaran dalam bertukar pendapat. Sebagai mediator, guru berperan mengaitkan materi dengan permasalahan nyata. Sebagai director-motivator, guru berperan membimbing, pemberi semangat agar siswa dapat menyampaikan permasalahanya. Sebagai evaluator, guru berperan menilai proses dan hasil belajar mengajar yang sedang berlangsung.

\section{METODE PENELITIAN}

Penelitian ini menggunakan metode eksperimen dengan desain pra eksperimental, dan menggunakan rancangan one group pretest-posttes design. Hal ini bertujuan untuk mendeskripsikan efektivitas penerapan pembelajaran kooperatif ditinjau dari kemampuan penalaran logis matematis siswa. Sampel penelitian ini berjumlah 38 siswa yang diambil secara proposive sampling dari dua kelas siswa pada suatu sekolah swasta di Kabupaten Halmahera Selatan. Prosedur penelitian ini adalah: (1) menetapkan satu kelompok siswa sebagai sampel; (2) memberikan tes awal (pretest); (3) menerapkan pembelajaran kooperatif untuk mengajarkan materi pernyataan majemuk dalam logika matematika; (4) memberikan tes akhir (posttest). Variabel penelitian ini yaitu pembelajaran kooperatif sebagai variabel bebas dan kemampuan penalaran logis matematis siswa sebagai variabel tak bebas. Data penelitian ini diperoleh secara langsung dalam kegiatan pembelajaran. Instrumen tes yang digunakan untuk pengumpulan data berupa lima butir soal berbentuk essay test. Intrumen tersebut disusun oleh peneliti berdasarkan indikator penalaran logis matematis dan telah melalui validasi ahli serta uji coba (try-out). Data hasil penelitian dianalisis menggunakan statistik uji One-Sample Test setelah mengetahui normalitas data kemampuan penalaran logis matematis siswa.

\section{HASIL PENELITIAN DAN PEMBAHASAN}

Deskripsi kemampuan penalaran logis matematis siswa SMA sebelum (pretes) dan sesudah (postes) pembelajaran kooperatif ditunjukkan pada Tabel 1. 
Tabel 1.

Deskripsi Kemampuan Penalaran Logis Matematis Siswa SMA Sebelum dan Sesudah Pembelajaran Kooperatif

\begin{tabular}{ccccccc}
\hline Pembelajaran & \multicolumn{7}{c}{ Statistik } \\
\cline { 2 - 7 } Kooperatif & n & Rerata & SB & KV(\%) & Maks & Min \\
\hline Pretes & 38 & 10,50 & 2,02 & 19,24 & 6 & 14 \\
Postes & 38 & 74,97 & 6,41 & 8,19 & 60 & 87 \\
\hline
\end{tabular}

$\mathrm{N}=$ Jumlah Sampal, SB=Simpangan Baku, KV=Koefisien Variasi, Maks=Maksimum, dan

Min=Minimum

Berdasarkan data Tabel 1 dapat dijelaskan bahwa: (1) Skor rerata, skor maksimum dan minimum data kemampuan penalaran logis matematis siswa sesudah pembelajaran kooperatif lebih tinggi daripada sebelum pembelajaran. Hasil ini menunjukkan bahwa pembelajaran kooperatif berkontribusi positif dalam menghasilkan kemampuan penalaran logis matematis siswa SMA. (2) Koefisien variasi data kemampuan penalaran logis matematis siswa sesudah pembelajaran kooperatif lebih kecil daripada sebelum pembelajaran. Hal ini menggambarkan bahwa sebaran kemampuan penalaran logis matematis siswa sesudah pembelajaran kooperatif lebih baik dibandingkan sebelum pembelajaran. Artinya, pembelajaran kooperatif mendorong terciptanya kemampuan penalaran logis matematis antara siswa SMA relatif homogen.

Perbedaan data kemampuan penalaran logis matematis siswa SMA sebelum dan sesudah pembelajaran kooperatif dapat juga dilihat secara histogram, diagram normal $Q-Q$ plot dan detrended normal $Q-Q$ plot Gambar 1.

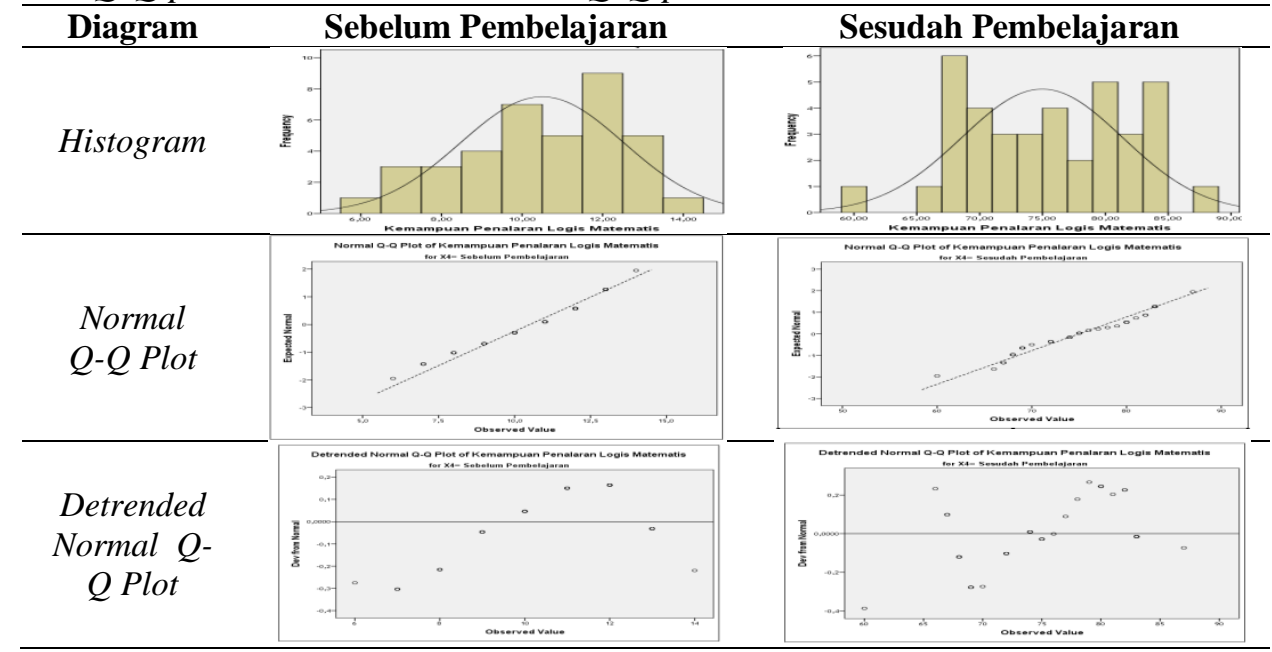

Gambar 1: Deskripsi Perbedaan Data Kemampuan Penalaran Logis Matematis Siswa Sebelum dan Sesudah Pembelajaran.

Berdasarkan Gambar 1 dapat dijelaskan bahwa, data siswa sebelum pembelajaran cenderung tidak normal dan sesudah pembelajaran cenderung normal. Artinya, penerapan pembelajaran kooperatif menghasilkan kemampuan penalaran logis 
matematis siswa yang relatif sama antara setiap siswa. Hasil penelitian diperoleh rerata sebesar 74,97 dari SMI 100, menunjukkan bahwa tingkat kemampuan penalaran logis matematis siswa SMA melalui pembelajaran kooperatif mencapai $74,97 \%$ atau tergolong baik.

Hasil uji statistik One-Sample Test tentang perbedaan rerata kemampuan penalaran logis matematis siswa sebelum dan sesudah pembelajaran dijelaskan pada Tabel 1.

\begin{tabular}{|c|c|c|c|c|c|}
\hline \multicolumn{6}{|c|}{ One-Sample Test } \\
\hline & \multicolumn{5}{|c|}{ Test $\mathrm{Value}=10.5$} \\
\hline & \multirow{2}{*}{ 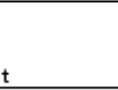 } & \multirow[b]{2}{*}{ df } & \multirow[b]{2}{*}{ Sig. (2-tailed) } & \multirow{2}{*}{$\begin{array}{l}\text { Mean } \\
\text { Difference }\end{array}$} & $\begin{array}{l}95 \% \text { Confidence Interval of the } \\
\text { Difference }\end{array}$ \\
\hline & & & & & Lower $\quad$ Upper \\
\hline Skor Postes & 61,989 & 37 &, 000 & 64,47368 & 62,3663 \\
\hline
\end{tabular}

Hasil analisis data pada Tabel 1 dapat dijelaskan bahwa: (1) selisih rerata kemampuan penalaran logis matematis siswa melalui pembelajaran kooperatif mencapai 64,47\% dari rerata pretes sebesar 10,50\%, dan (2) hasil uji One-Sample Test diperoleh nilai signifikansi sebesar 0,000 kurang dari $\alpha=0,05$, sehingga $\mathrm{H}_{0}$ ditolak. Artinya, kemampuan penalaran logis matematis siswa SMA sesudah pembelajaran kooperatif secara signifikan lebih tinggi daripada sebelum pembelajaran. Hal ini menunjukkan bahwa pembelajaran kooperatif dapat meningkatan kemampuan penalaran logis matematis siswa. Rerata peningkatan kemampuan penalaran logis matematis siswa yang dihitung berdasarkan rumus gain ternormalisasi Hake (1999) sebesar 0,72, tergolong peningkatan tinggi.

Berdasarkan penjelasan tersebut dapat disimpulkan bahwa, pembelajaran kooperatif dapat meningkatkan kemampuan penalaran logis matematis siswa SMA pada pembelajaran logika matematika. Kemampuan penalaran logis matematis siswa SMA melalui pembelajaran kooperatif dalam kualifikasi baik, dan peningkatannya tergolong tinggi. Hal ini menunjukkan bahwa pembelajaran kooperatif efektif dalam meningkatkan kemampuan penalaran logis matematis siswa SMA.

\section{KESIMPULAN}

Berdasarkan hasil dan pembahasan diatas, dapat disimpulkan bahwa: (1) Kemampuan penalaran logis matematis siswa SMA melalui pembelajaran kooperatif dalam kualifikasi baik, dan peningkatannya tergolong tinggi. (2) Pembelajaran kooperatif signifikan dalam meningkatkan kemampuan penalaran logis matematis siswa SMA. (3) Pembelajaran kooperatif efektif dalam meningkatkan kemampuan penalaran logis matematis siswa SMA pada pembelajaran materi pernyataan majemuk logika matematika.

Berdasarkan kesimpulan tersebut dikemukakan saran berikut: (1) Pembelajaran kooperatif hendaknya digunakan sebagai alternatif model pembelajaran untuk 
meningkatkan kemampuan penalaran logis matematis siswa, (2) Penerapan pembelajaran kooperatif hendaknya guru kreatif dalam menyusun rencana pembelajaran, dapat menciptakan suasana kelas yang mendorong terbentuknya kemampuan bernalar siswa, mampu memposisikan diri sebagai fasilitator, mediator, dan evaluator secara professional, dan (3) Hasil penelitian ini dapat dijadikan rujukan bagi pengembangan penelitian selanjutnya, terutama tentang peningkatan kemampuan penalaran logis matematis dan penggunaan model pembelajaran kooperatif.

\section{DAFTAR PUSTAKA}

Barnes, 1992. Mathematical Thinking.McMillan Publishing Company, New York. Baroody, A.J.,(1993). Problem Solving, Reasoning, and Communicating, (K-8). Helping Children Think Mathematically. New York: McMillan Publishing Co.Inc.

Bruning, H., \& G.J. Schraw, \& R.R. Ronning, (1995). Cognitive Psycology and Intruction, Second Edition, Merril an imprint of Prentice Hall, Englewood Cliffs, New Jersey.

Dehghan Shadkami, M. (2009). The Effects of Cooperative Learning on the Progress and Self-Respect of girl students, Tehran guidance schools. MS Thesis, Islamic Azad University, Science and Research branch.

Ennis, H., (1996). Critical Thinking. Prentice Hall, Upper Saddle River, NJ 07458, New Jersey.

Gallagher \& Reid. (2002). The Learning Theory of Piaget and Inhelder. United America States: Universe.

Hossaini Zavaran, M. (2005). The effects of Cooperative Learning on Social Skills, Educational self-esteem, and the Educational Effort Mathematic Subjec;, Third grade students, Zarin dasht.

Isjoni, 2010. Cooperative Learning Efektivitas Pembelajaran Kelompok. Alfabeta, Bandung.

Johnson, D., \& Johnson, R. (1989).Cooperative and Competition: Theory and research Endia, Mn: Interaction Book company.

Kagan, S. (1994). Cooperative Learning. Sanclement, CA: kagan publications.

Keramati, M. R. (2008). The Effects of Cooperative Learning on Academic Success of Physics subjects., Journal of Psychology and Educational Sciences. 38(2), 147-165.

Matlin, M.W., (1994). Cognition, Third Edition. Harcourt Brace Publishers, Forth Worth.

Mirzakhani, M., Yatyari, F., \& Kadivar, P. (2008). The Effects of Cooperative Learning Self-Respect and Social Skills on the Academic Achievements of high school students. Periodical on Science and Psychological Research, Tabriz University, 10. 
Redhana, I Wayan. 2003. Meningkatkan Keterampilan Berpikir Kritis Siswa Melalui Pembelajaran Kooperatif Dengan Strategi Pemecahan Masalah.Jurnal Pendidikan Dan Pengajaran XXXVI. II: 11-21.

Slavin, R. E. (1991). Synthesis of research on cooperative learning . Journal of Educational Leadership, 48,5, 71-82.

Suryadi, D.,2010. Metapedadidaktik dalam Pembelajaran Matematika: Suatu Strategi Pengembangan Diri Menuju Guru Matematika Profesional

Markaban 2004. Logika Matematika. Departemen Pendidikan Nasional, Direktorat Jenderal Pendidikan Dasar dan Menengah, Pusat Pengembangan Penataran Guru (PPPG) Matematika, Yogyakarta.

Slavin, R.E., \& karweit, N. (1981). Cognitive and Affective Outcomes of an Intensive Student Team Learning experience. Journal of Experimental Education, 50, 29-35.

Sumarmo, U. (2004). Pembelajaran Keterampilan Membaca Matematika pada Siswa Menengah. Makalah disajikan pada seminar nasional. FKIP, UNSWAGATI: tidak diterbitkan.

Schwartz, St. P., (1994) Fundamental of Reasoing. New York: McMillan Publishing Company.

Zourabadi, A. (2003). The Effects of Cooperative Learning on the Social Development and Self-Respect of 5th grade elementary students in Jovin, Sabzevar. MS Thesis, Faculty of Psychology, Allame Tabatabaie University. 